\title{
The Capitalism of Chambri Cosmology: \\ The 2017 Sir Raymond Firth \\ Memorial Lecture
}

\author{
Deborah Gewertz \\ and Frederick Errington
}

$\mathrm{R}$

aymond Firth's I954 presidential address to members of the Royal Anthropological Institute of Great Britain and Ireland was titled "Social Organization and Social Change." It concluded with this advice (in paraphrase): To understand social change-whether in structure, "in which basic elements of the society alter," or in detail, "in which social action while not merely repetitive, does not alter the basic social norms"-it is necessary to study closely "the setting and results of individual choice and decision" (Firth I954, I7). In other words, it is necessary to look carefully at social organization. Indeed, as stated earlier in his address and implicit in his emphasis on long-term fieldwork, although structure provides a framework for action, circumstances may lead to "fresh choices" and "fresh decisions" (Firth I954, 4). These choices and decisions may ripple throughout a structural framework and, sometimes, beyond it. When this departure from a structure becomes permanent, the result is social change.

Thirty-four years later, social change was still on the mind of another distinguished scholar delivering another influential address. This was Marshall Sahlins in his I988 Radcliffe-Brown Lecture in Social Anthropology, "Cosmologies of Capitalism." It reflected his earlier formulation of the "structure of the conjuncture" as "the practical realization of the cultural categories in a specific historical context, as expressed in the interested action of the historic agents, including the microsociology of their interaction" (Sahlins I985, xiv). This process, with its focus on choices, decisions, and motivated engagements, is, as Sahlins explicitly referenced, "reminiscent of Firth's distinction between a de facto 'social organization and a de jure or underlying 'social structure'” (I985, xiv). Sahlins's

The Contemporary Pacific, Volume 32, Number I, I24-I45

(C) 2020 by University of Hawai'i Press

I 24 
particular interest (and one he carried through to some extent in his 2008 Raymond Firth lecture, "Alterity and Autochthony," at the meetings of the European Society for Oceanists) was in understanding the ripples of social change that ensued during the conjunctures of capitalism with local systems of meaning, practice, and structure. Thus, in his RadcliffeBrown Lecture, he showed that local peoples (the Chinese, Hawaiians, and Kwakiutl as examples) "struggle to integrate their experience of the world system in something that is logically and ontologically more inclusive: their own system of the world" (Sahlins I988, 4). In essence, Sahlins argued that capitalism has taken various cosmological forms as people, through their choices and decisions, have attempted to harness it, generally to augment themselves according to existing standards-to become more of what they already were.

Of course, culturally embedded choices and decisions are frequently compromised. They may ramify in ways that are difficult to control (as with escalating potlatch competitions), or they may be rendered nugatory (as with opium wars and other forms of external coercion). And, of special importance to us here, they may be compromised when the cosmologists working to indigenize capitalism are themselves significantly changed by the (often ongoing) conjunctures. We stress that part of capitalism's ripple effect may be to change the deciders and choosers into those who actively desire fresh, structure-breaking choices and decisions.

Concentrating on the Chambri of Papua New Guinea's East Sepik Province, whose three home villages on Chambri Island line the shore of fish-rich Chambri Lake (map I), we consider a salient set of ripples: ripples opening up the ontologies of Chambri totemic practice to the possibilities of capitalist-inflected choices, decisions, and agents. In so doing, we explore historically the ongoing process that is the multigenerational capitalism of Chambri cosmology. While there have been changes in the winds, waters, and fish on which the Chambri rely, our primary concern is not with these environmental changes per se. Rather, it is with Chambri responses to these changes. They see them as caused by a problematic shift in the ritual practices through which their surroundings are regulated. ${ }^{1}$

We should mention that this article is part of a larger retrospective project, one that probes changes between I974 and 2015. This larger project involves tensions and complementarities between rural and urban economies and socialities as they engage both men and women. Here, however, our focus is on one dimension of the numerous shifts that have affected Chambri during the multiple decades of our ongoing field research: envi- 


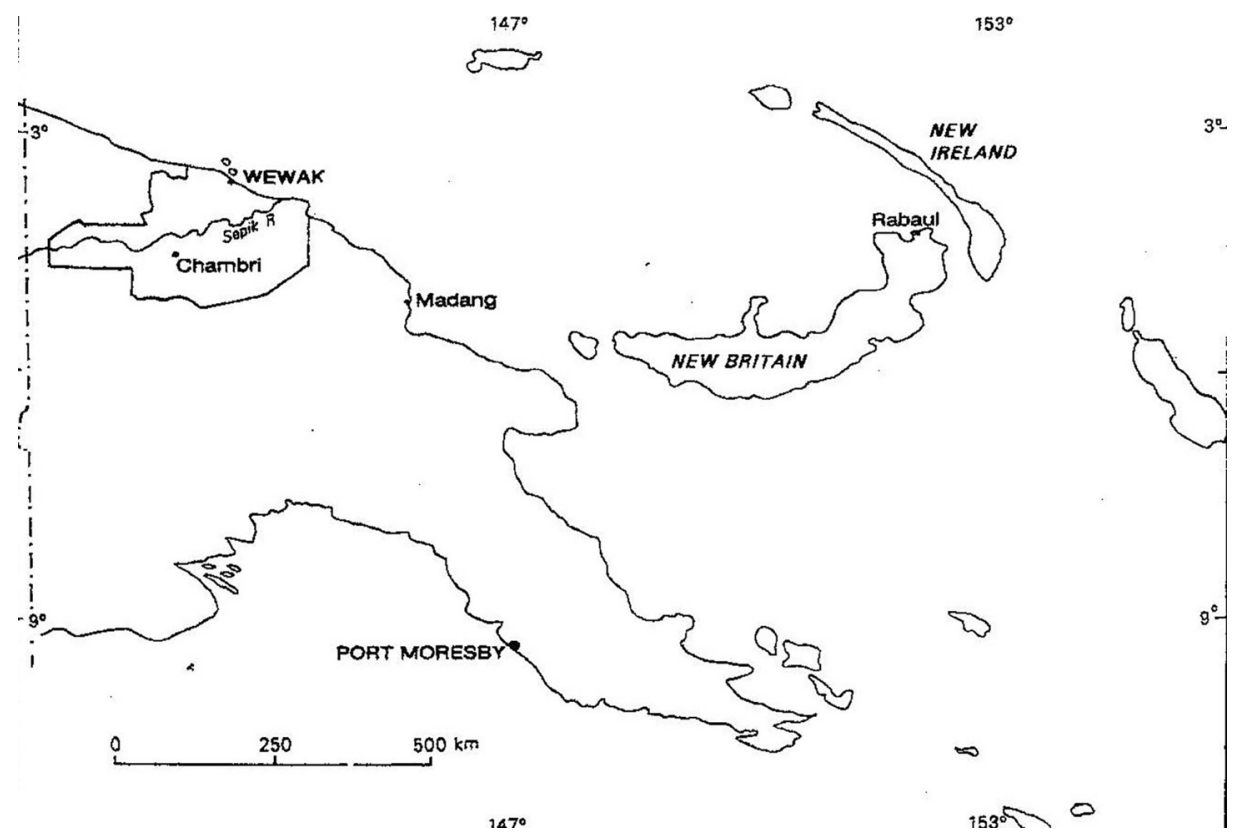

MaP I Map of Papua New Guinea showing the Chambri Lake region.

Copyright the Australian National University, College of Asia and the Pacific, CartoGIS. Reproduced with permission.

ronmental regulation as it is effected through village-based, male-oriented, totemic practices. ${ }^{2}$

\section{Totemism as a Protection Racket?}

During the Christmas holiday of 2015 , we visited Chambri Island. Regularly sitting with Klara Wali on the porch of her permanent-materials house, we caught up on village events. ${ }^{3}$ Cell phones were ubiquitous; solar panels were common. Women were earning money through the sale of smoked fish, but men were largely idle. Few, if any, were carving artifacts as they once had because tourism had virtually ceased. One day, our musings about continuities and changes were interrupted as five men, all in their early forties, filed purposefully past along the main path. As wage earners home on holiday break, they were worried that the high waves of Chambri Lake would prevent their timely return to their jobs.

Indeed, the lake had become increasingly erratic in recent years. This was understood as being partly the result of the introduction by fisher- 
ies experts of an exotic species of fish, the pacu (Colossoma macropomum) (figure I). Intended to enhance Chambri subsistence, the fish did prove meaty and tasty; it also proved alarmingly omnivorous. Prior to the pacu's arrival, Chambri Lake had been filled with floating grass islands, waterlilies, and extensive grassy fringes extending some 50 meters into the

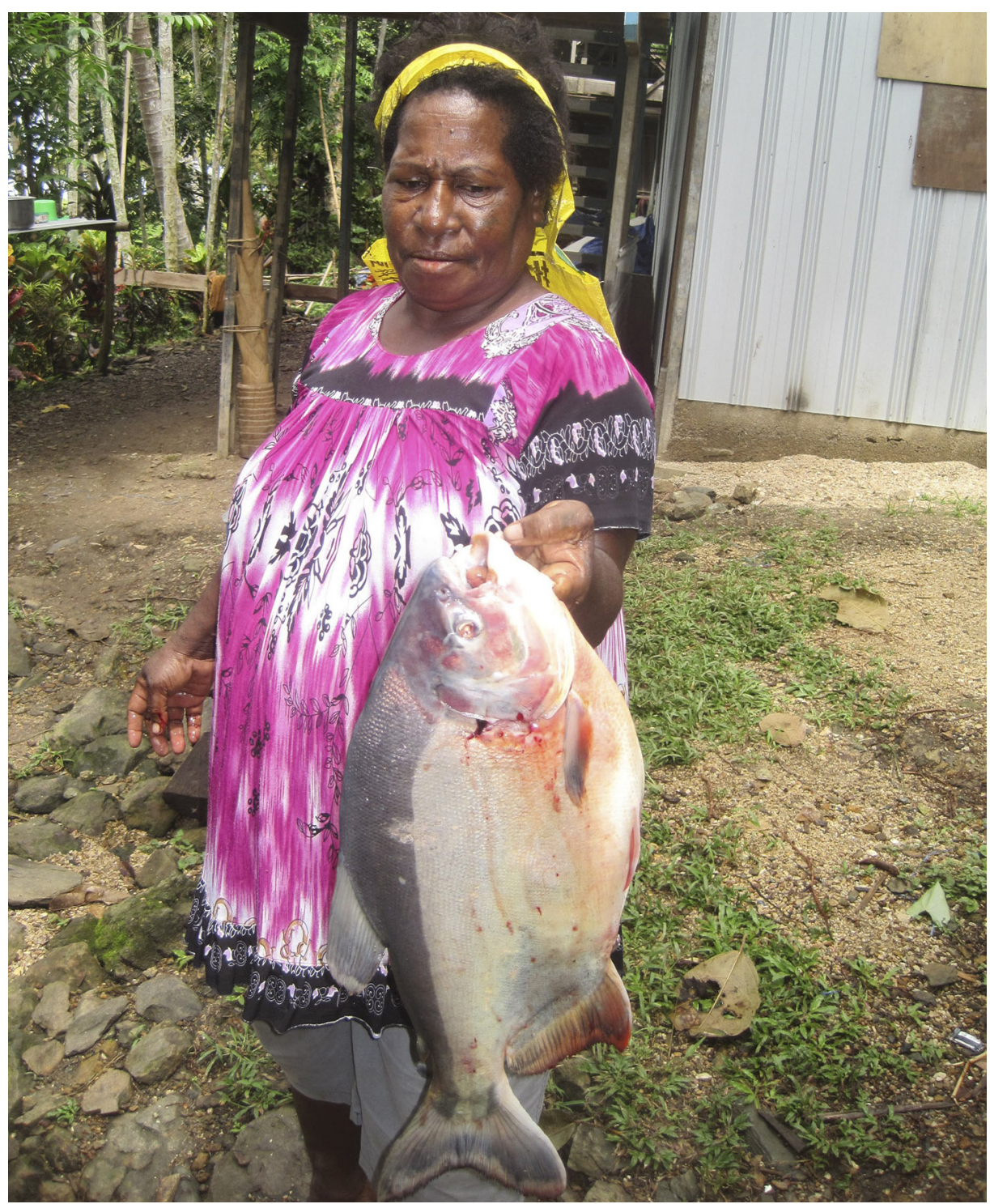

Figure I Klara Wali with a pacu, 2 January 2015, Indingai Village, Chambri Island, Papua New Guinea. Photo by Frederick Errington. 


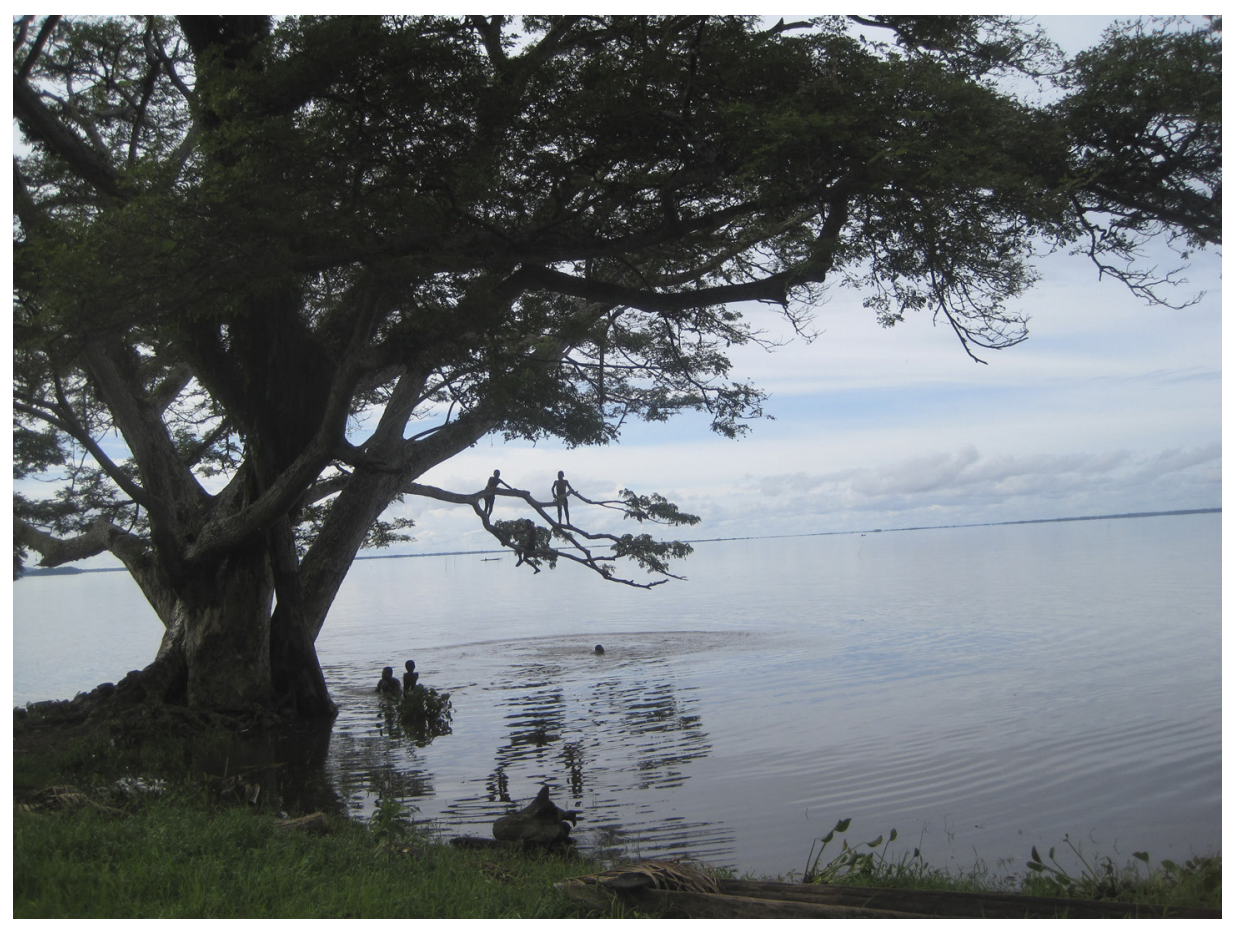

FIgURE 2 Chambri Lake cleared of vegetation, I9 January 2015, Indingai Village, Chambri Island, Papua New Guinea. Photo by Frederick Errington.

water. All of this vegetation had been eaten by the fish, leaving nothing to obstruct the actions of the wind and the waves (figure 2). ${ }^{4}$ Traveling across the lake had become periodically dangerous, even in a motorboat. And it had been this way for several days.

The pacu were not the only cause of the rough water. The five men passing Klara's porch were on their way to deal with the more proximate cause; they were intending to pay the totemic practitioner who had riled up the water so that he would calm it down. Klara explained with some consternation that this was not how it once worked. As we were to discover from her and others, senior men were no longer using their clanbased secret names and special powers as part of a totemic division of labor. No longer were they coordinating the regulation of their respective portions of the Chambri environment—among them the winds, waters, and fish. ${ }^{5}$

On the one hand, the lake often seemed unregulated, to have acquired a life of its own. On the other, when controlled, it was often by the wrong 
person and for the wrong (purely selfish) reasons. The current practitioner, acting as an entrepreneur, was neither totemically authorized nor even of the right clan. He had bought the magic as a business investment from its hereditary holder, a cash-short old man. Most distressing from the perspective of many Chambri, the sole point of his "business" practice was to make trouble so that people would pay him to stop. These people included women catching fish to sell at regional markets, as well as the likes of our five Chambri workmen. In effect, this totemism was a protection racket.

We knew, of course, that totemic practitioners of the past had not been above causing others trouble. Nor had they eschewed gifts of appreciation, such as those offered by women who were especially successful in catching a particular species of fish. Furthermore, we knew that the lake and other aspects of the Chambri environs had always been capricious. Yet, with this fragmentation and commodification of cosmology, many Chambri worried that a threshold had been crossed concerning the way totemic powers were now being used. This compelled a stocktaking. How had their history of choices and decisions made at least some Chambri so commercially self-interested?

\section{Our Totemic Baseline}

When Deborah first arrived at Chambri in 1974, the totemic division of labor, with its mix of competition and cooperation, was active-despite systematic European contact since the I930s, including a resident European Catholic priest since the I950s. Awakened by booming slit gong drums, men would converge in elaborate men's houses to debate, in archaic Chambri, about their ritual prerogatives (Gewertz 1977). Displaying immense "communicative competence ... the knowledge and ability to speak in socially appropriate ways" (Bauman I975, 293), debaters would mingle dance and oratory. Competing for leadership—to become big men in their fundamentally egalitarian social system - they would allude to their secret totemic names and attendant special powers: to those names and powers connecting their identity with the crocodiles and other ancestors that had established Chambri as people and Chambri Island as place, to those ensuring the vitality of their patriclans and their capacity to attract wives, to those making their rivals fearful, and (as mentioned) to those regulating their portion of the universe in its succession of seasonal changes.

In I974, the dry season was uncommonly long, and much of Chambri 
Lake had been reduced to mud flats. The rains, when they finally began, were sporadic and light, creating myriad shallow puddles in the lake bottom. While the people were accustomed to the mosquito-ridden transition seasons, the ensuing swarms were so dense that Chambri men called a three-village meeting at a central men's house. The meeting began in the morning and lasted throughout the day. The debaters dealt with four related questions: Which ancestor was responsible for bringing these mosquitoes? Why had the ancestor brought them? Who had the power to invoke that ancestor? Who was in fact doing this?

It was quickly agreed that the ancestors Mali and Yambukei were responsible for the plague. No one doubted this; their descendants openly admitted it. However, which of the descendants was responsible for invoking them was not at all clear. Nine men were named by debaters as potentially having the power to bring the mosquitoes. Six of these were present at the meeting, but one immediately denied any responsibility, asserting that, as a recent widower, he thought of nothing except his dead wife and young, motherless children. Each of the remaining five justified his ancestors' actions, stating a range of possible reasons why Mali and Yambukei were angry. Principal among these was that Chambri had failed to respect them for their vital totemic services; in particular, Chambri had failed to show proper appreciation to these ancestors for the variety of wild fruits they provided to their descendants. Hence, it was proposed, Mali and Yambukei were angry because they had not received the annual tribute for their services, because they had not been thanked by women who sold their fruits at markets, and because the seeds of their fruits were heedlessly scattered about by Chambri children. In addition, their ire might have been aroused by the embarrassingly drunken behavior of a Chambri man when visiting the Iatmul village of Sepik River rivals.

Each of these putative reasons for such ancestral anger was extensively discussed by debaters. Some of the men imitated pigs and chickens following Chambri children to eat the wild fruit seeds dropped carelessly from their hands. Others mimicked the drunken Chambri's garbled and abusive conversation with the Iatmul villagers. The spectators appreciated the skill—the virtuosity - that these performances demanded. Although they laughed at the mime and at each lewd, drunken remark, they were alert for mistakes. Hour after hour, in various performative registersboth serious and farcical-the debaters sought to impress their allies and intimidate their rivals. By alluding to their totemic knowledge and therefore their totemic power, they contended over much that then mattered: 
the inheritance of the powerful names necessary to control wind, water, and a diversity of life forms, as well as to compel respect from others.

Crucially linked with and reflecting the power/knowledge system of Chambri totemism evidenced in these debates was the fact that eminent men retained and manifested their power by arranging strategic marriages for themselves and their children. These were marriages that commanded high bride prices (figure 3); marriages that upheld and ordered multigenerational alliances (as with mother's brother's clans); and marriages that ensured that their sons joined them, together with their in-marrying wives and children (the latter as new members of the patriclan), in large and impressive houses.

Importantly, the reproduction of this power/knowledge system meant that the choices and decisions of senior men were made at the direct expense of the choices and decisions of junior men. Certainly, the system was seen by juniors as structured to keep them in their place. Social succession was difficult not only because the performative ballet of men's house debates was dauntingly demanding but also because the senior men wished to maintain their positions of power as long as possible. Reluctant to step aside for their juniors, senior men would delay conveying, virtually until their deathbeds, the knowledge requisite to debate. Furthermore, senior men also wished to augment their power through the appropriation of new opportunities in the form of the cash and commodities that had begun to ripple through their system (much as the Kwakiutl and Hawaiians did in Sahlins's analysis). They pressured at least one of their sons to get an education and a well-paying job. Remittances, it was hoped, would enhance clan prestige and continuity by enabling bigger and better bride prices. By 1983, during our first joint trip to Chambri, such a large cash bride price was presented that the groom's father bragged that his clan could kill the bride because her death compensation had already been paid.

\section{Young Lives}

In 1987, by the time of our next field trip, the same ripples that allowed clan leaders to conceive of becoming more of what they already were allowed their sons to conceive of becoming less of what their fathers wanted them to be. In "opposition to the effects of power" that were, as apparent in the men's house debate, "linked with knowledge, competence, and qualification," these young men confronted the question of "Who are we?" (Foucault 1982, 78I). Using English to denote their modern- 


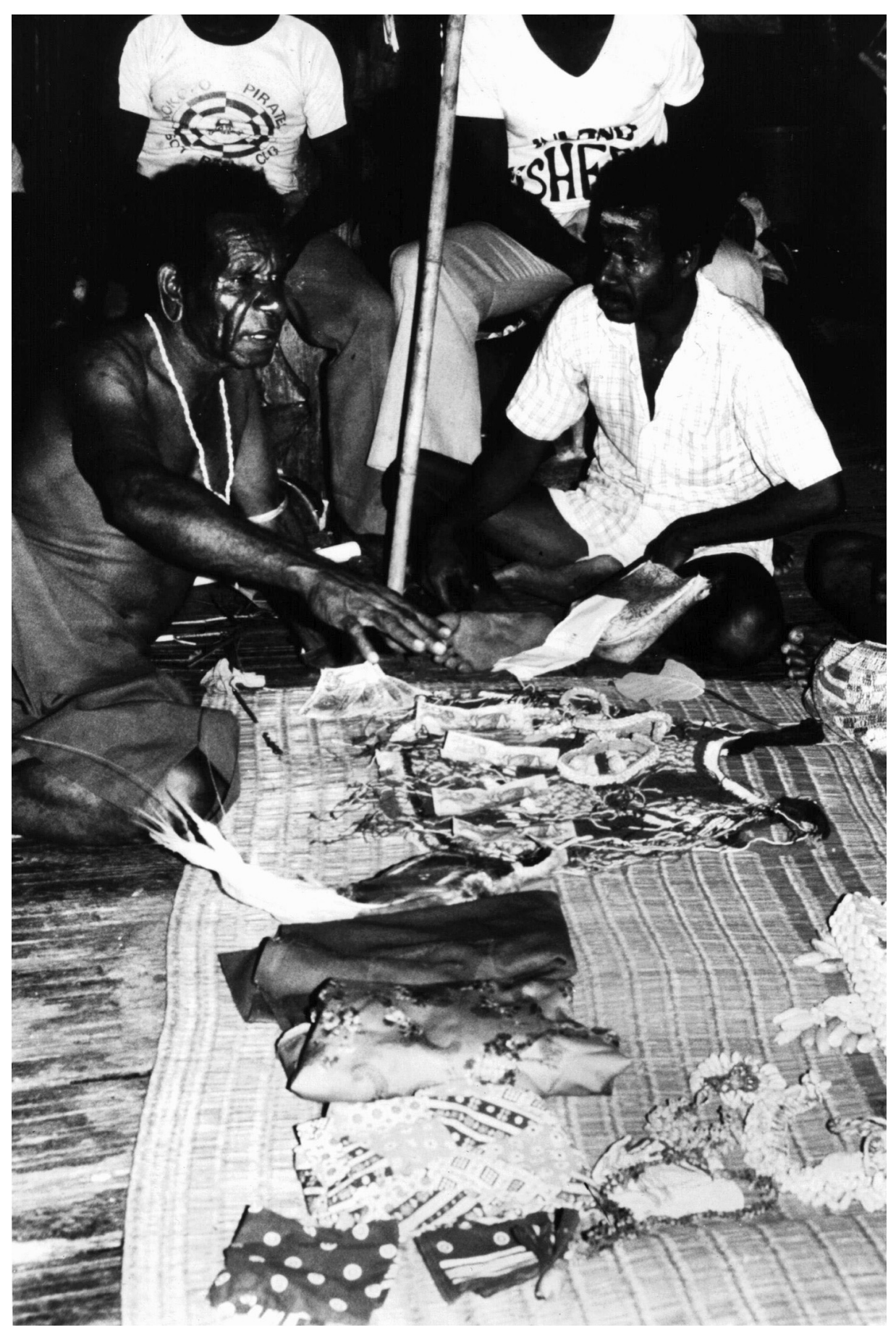

FIgURE 3 Eminent men amassing bride price, 26 December I983, Kilimbit Village, Chambri Island, Papua New Guinea. Photo by Frederick Errington. 
ist identities, they termed themselves "young lives." Indeed, the choices and decisions these young men exercised were explicitly directed toward participating in another system, one building since a variety of late nineteenth- and early twentieth-century "first contacts" and becoming increasingly pervasive since independence in I975. They were self-styled "young challengers," using Pierre Bourdieu's term, struggling against orthodoxy so as to make their own choices and decisions; they were struggling, and this too is Bourdieu, to make "their [own] mark ([or] 'epoch')." In effect, this would not be possible "without pushing into the past those who [had] an interest in stopping the clock, eternalizing the present stage of things" (Bourdieu I983, 60). At this time, these young lives embraced a system ostensibly premised on personal choice: one that conjoined freedom of religious choice, freedom of commodity choice, and freedom of marital choice. Of these three, marital choice was by far the most subversive, at least on Chambri Island.

Thus, in what became a cause célèbre among young men talking to us about the repressive actions of big men, was the story of the defiant Philip Biap. It was over performances of Philip's Yerameri Drifters Band that the big men had instituted a ban on all-night dances. Chambri young men and women, we discovered, frequently sang Philip's songs, sometimes to the accompaniment of cassettes they had made of him and his band.

Philip's songs blended what Chambri regarded as traditional and modern elements. The lyrics consisted of a brief Chambri phrase repeated over and over, and they were concerned with themes of love and rebellion and were set to string-band music. The following eight songs (in translation) were the entire corpus of Philip's music:

Come here. [This was addressed to his girlfriend.]

Father, mother, I don't belong here.

Mama said slow down. [But Philip did not listen.]

Mama said so. [But Philip did not listen.]

She follows me when I walk about. [This referred to the devotion of Philip's girlfriend.]

You're too loud. [This was what the big men said about Philip's music.]

You don't want to wait for your boyfriend. [Philip was trying to convince his girlfriend to reject the man arranged to be her husband.]

Bernadette. [This was the name of Philip's girlfriend, later his wife.] 
It was clear that, for Chambri youth, the power of these songs of love and rebellion came in significant part from Philip's own circumstances. Whereas other young men and women we had known had fled Chambri for the town of Wewak instead of acceding to arranged marriages or other forms of coercion, Philip, after attending vocational school in Madang for a year, had chosen to remain in Chambri and challenge his elders. He had defied his father, we discovered, by marrying Bernadette, the woman of his own choice. His subsequent and lamentable death was unfortunately, in the view of young Chambri men and women, entirely predictable. They were convinced that his father had killed him through sorcery for his obduracy. He was not afraid to defy the big men; he insisted, we were told, that "young lives" should be allowed to marry as they choose.

Regardless of whether Philip thought his intransigence might end in his death, the extent of his opposition to his father was impressive and instructive. It testified to the appeal to Chambri youth of the novel possibilities inherent in Western concepts of freedom of choice. These possibilities were implicit in recent teachings by the Catholic Church that stressed the importance of freely entered "Christian marriage" and in popular literature, music, and advertising that extolled stylishness and the importance of fulfilling desire and romance. For example, a typical advertisement in a Papua New Guinea newspaper might be for the very expensive Nissan 280zx. Depicted with two attractive Papua New Guinean women draped on hood and trunk, the Pidgin English caption (translated) stated that "it should be acquired by everyone who wishes to have a good time" (Mathie and Cox 1987, I7). Young men pinned such sexy advertisements to the walls of their houses (all to be posted on Facebook nowadays). Young women clipped pictures from magazines. One showed us an extensive collection that she kept in an old school notebook. Her pictures were of white women, posed in romantic settings like rose gardens, wearing formal, frilly dresses-frequently bridal gowns. She had underlined several of the captions, including: "With the rustle of silk and the hint of tulle, you will be the envy of all single girls. Make sure you choose the dress of your dreams on your wedding day." 6

If these choices and decisions were not structure-breaking, they were at least structure-cracking. And the big men knew this. Their children were not only increasingly defying them; they-their sons especially-were disinterested in acquiring their totemic knowledge and attendant performative skills. In essence, as young lives, the kids were both attacking the system and opting out of it, demanding that stock be taken. One big man, 
Andrew Kwoli, did exactly that, albeit unsympathetically. In 1987, while recounting Chambri myths to us, he began to recite secret names as a group of young men played ukuleles nearby. He told us, disdainfully, that these young men were so ignorant that they did not even recognize that the names they were hearing were secret.

\section{Who Wants to Be the Catfish?}

On I8 July I994, Moses Tari, a Chambri elder, summoned us to a demonstration of some of his most important, patrilineally inherited totemic powers. He asked us to take notes, photograph, and tape-record him as he became, quite literally from his perspective, a species of catfish—or, much the same thing, as he became the ancestor who was or could become that catfish. Recognizing that young men were currently disinterested in mastering the highly specific names and procedures that effected this embodiment, he hoped that our documentation might preserve his knowledge for some future generation. By 1994, many Chambri elders had moved from disdain to alarm at the "newcomers" assertion of "difference." In fact, those with young lives wanted to get themselves known and recognized by endeavoring to impose new "modes of thought and expression." These new modes disconcerted the "orthodox," who were rightly concerned (Bourdieu I983, 57-58). They feared that, with the increasing loss of their corpus of cosmological knowledge and attendant practice-the doxa-the totemic division of labor through which they had regulated their world would no longer be viable. In addition, these elders knew that for many Chambri the necessity of earning money for flashlight batteries, clothing, school fees, and sometimes outboard motors was more pressing than taking their part in regulating the cosmos. Moreover, as we shall soon see, it was increasingly plausible that Christianity could be a force in ordering the Chambri world.

When we arrived at the appointed time, Tari cleared his house so that just he, his wife, and we remained, and he closed the doors so that no one else could see in or interrupt. After inserting totemically significant leaves in his earlobe holes, he went to a large sago storage pot previously moved to the center of the room. From that pot, he retrieved a bamboo flute and a small clay flute, which he placed in a string bag hung from the central post of the house. After walking to the door, he then turned to face the central post and the flutes hanging there. Uttering a set of esoteric multisyllabic names with great seriousness and intensity, he stamped his 
foot, pressed crossed arms against his chest, and paced deliberately back toward the objects. As he paced, he sucked sharply through his pursed lips to make two alternating sounds-the sounds of the catfish. Then, flutes in hand, he posed for photographs, standing in back of the sago pot and beside his seated wife.

We of course had long been aware that there were comparable ritual procedures throughout the Middle Sepik. Gregory Bateson, after all, had described "immanent totemism" as widespread in this region: "In every village you find the living embodiments of the ancient mythology-the man who bears the name which was once borne by the founders of the village. He will straighten his shoulders as he tells you 'I steered the canoe which brought my clan to this place.' Another man will stamp on the ground as he says 'I am Kevembuangga. I put my foot on the mud and made it hard so that people could live. But for me there would be no people. There would be no pigs'” (I946, I2I).

For Tari's part, after his cosmologically salient embodiment, we were ushered into his men's house-the single elaborate one standing-where junior clansmen had been assembled for their instruction. He had us tape-record and photograph him playing distinctive rhythms on a totemically proper slit gong drum. He then had us photograph him sitting on the men's house bench appropriate to his clan and its powers. Finally, he charged us to include his story-everything, the photographs, descriptions, and names-in our next book to provide a consultable record of his importance and his knowledge. ${ }^{7}$

\section{A Grand Yet Fleeting Synthesis}

In fact, by I994, many senior Chambri men had asked us to tape-record their corpora of ancestral names, chants, and stories lest they be lost. At the same time, one somewhat younger and still vigorous man was reveling in an upward trajectory. Michael Pandu, with the help of remittances from his sons, had recently sponsored, as he explained to us, a large and very expensive ceremony for the construction and naming of a huge motor canoe. His expectation was that his future would be even better than his present. This was the case because his already extensive powers to regulate the high and low water levels of Chambri Lake and to control the reproduction of several species of fish-something he described as a "public service" - had been further augmented by divine power. He was receiving visitations from Jesus, with whom he had first conversed, in the Cham- 
bri language, on I7 August I99I at 3:00 AM. While still exercising his ancestral prerogatives, he could now do this through the more efficacious medium of the Holy Spirit (figure 4); this was preferable to the uncertain and often hazardous medium of complicated incantations and manipulations of ritual paraphernalia. Commensurate with the augmentation of his powers, he wished to extend his connections abroad. We were therefore instructed to send him a photograph of one of Deborah's classrooms with students shown standing in front of a picture of him projected on a screen. Also to be included in this picture was a table on which was placed a Catholic Bible and a carving he knew we owned of his ancestor Saun. With the picture should be the names and the addresses of the female students portrayed. His son could examine the picture, correspond with the students he fancied, and then, perhaps, choose from among them.

Pandu died in 2008 . He had been regarded as one of the last of the oldstyle leaders. By the time of our 2015 visit, just the posts of his large residential house remained. His men's house was in shambles, his networks fragmented, and many of his ritual powers dispersed. Karitas Pandu,

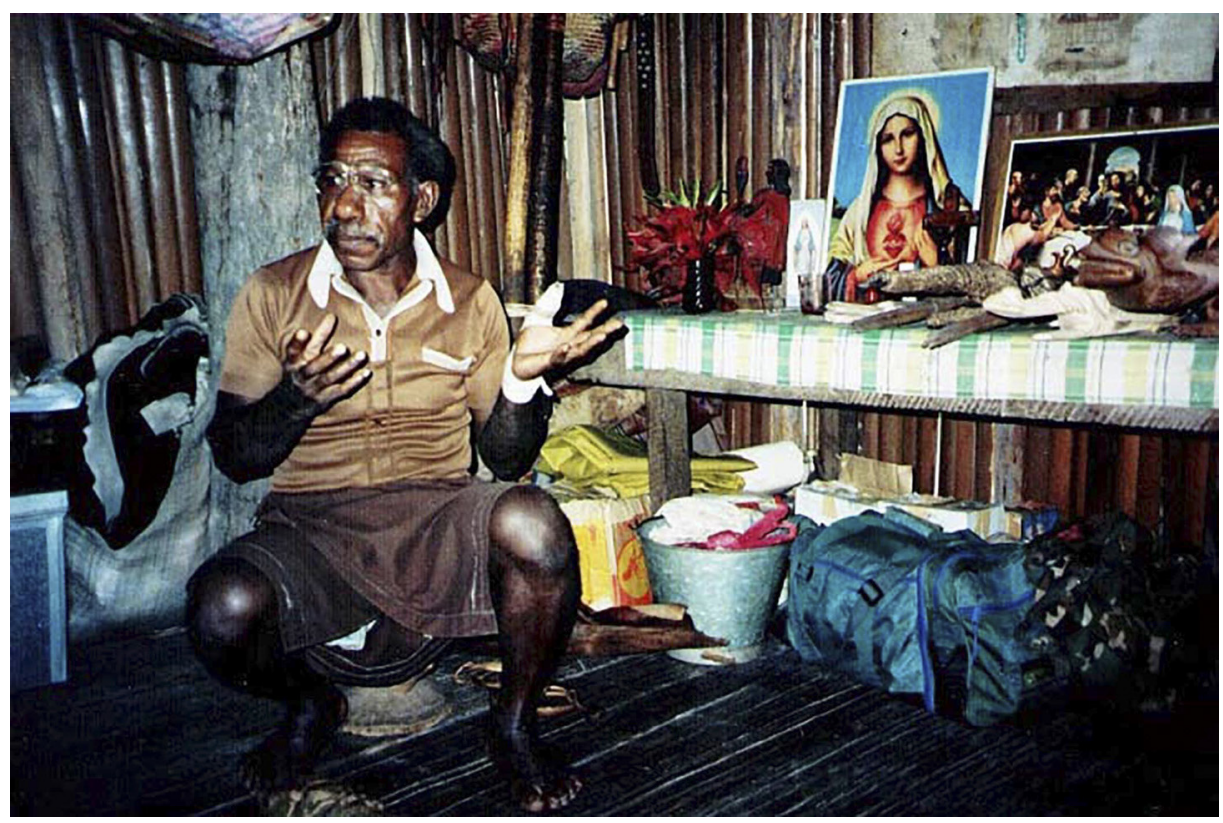

Figure 4 Michael Pandu with his coordinated ancestral and Christian powers, I 5 October 1987, Indingai Village, Chambri Island, Papua New Guinea. Photo by Frederick Errington. 
the only of Pandu's sons still living at Chambri, told us more about his father's death. Pandu had fallen under the influence of a hardcore totemist, who convinced him to return to his earlier reliance on ancestral power alone. Jesus, resenting Pandu's apostasy, became a wrathful God-afflicting him with a boil that, when scratched, resulted in Pandu's precipitous decline.

Typically and problematically, his father had held onto his secret names and consequent powers until the very last, transmitting little to his sons. The loss of such secret names-and not from his clan alone-was evident, Karitas thought, in the undeniable changes in Chambri Lake. As mentioned earlier, the floating grass islands, the water lilies, and the shoreline grass fringe had disappeared, and the increased winds and waves frequently made fishing and boat transportation difficult. To be sure, Karitas and other Chambri agreed, the introduced pacu contributed to these changes. Nevertheless, if ritual controls had been in place, the consequences-primarily of wind and wave action-would have been limited. Indeed, Chambri ritual power more generally had been dispersed. No one seemed able to consolidate and hold as much power as when Pandu, acting in concert with other practitioners, regulated the Chambri environment. As Karitas put it, "nature" (the English term used) had become a separate domain. No longer totemically regulated, it often just followed its own patterns. ${ }^{8}$

\section{Young Lives Come of Age}

Deborah had known August Soway since he was a baby. In I994, he was an unmarried twenty-two-year-old. The son of the first successful tradestore owner on Chambri Island, he had been sent to Wewak, where we were then living, to replenish his father's stock. While he was staying in Chambri Camp, a case of beer, a case of canned mackerel, and case of cooking oil were stolen from him by other Chambri, including a very close relative-his own mother's brother's son. Immediately after the theft, Soway informed us in distress that he intended to live his future as a "white man"- as, he explained, someone beholden to, and trusting of, no one. Much to his relief, Chambri rallied around him and compensation was paid. However, he told us on several occasions that he favored relaxing the demands of Chambri custom. For instance, his and his father's future-mostly as it pertained to their business-would be brighter if they (and other Chambri) were not obligated to disperse large sums of money on expensive funerals, initiations, marriages, and the like and if they could 
own and develop land individually rather than as members of large kinship groups.

In 2015 , at 42 , Soway was living on Chambri Island and still helping his father with the trade store. In addition, he expanded the family enterprise into crocodile farming and was working as a motorboat driver. Although he had acceded to an arranged marriage, he and his wife were living apart. He was trying to extricate himself from the marriage, but her family would not give back the money paid in bride price. Moreover, his girlfriend, also in an arranged marriage, was in an even worse predicament since her husband was abusive. That said, the lovers had become evangelical Christians, putting their faith in God. For the girlfriend's part, she told us that God would eventually uphold her right to choose a husband she loved.

In updating us on Chambri Island happenings since our last visit, Soway pointed out that most of the big residential houses were gone and a single men's house remained. With the collapse of tourism and the market for artifacts, men were largely unoccupied. ${ }^{9}$ Young men in particular rarely had anything to do; nevertheless, none wanted to be on the school committee or to train as the next catechist. The usual excuse, generally met with amusement, was that they would be busy starting their own business. Yet all they really wanted was to be given money by their fish-selling mothers for home-brewed, distilled liquor and for marijuana. ${ }^{10}$ Furthermore, Soway told us, they were using "black magic" so that their enemies would lose all control when drunk and get into trouble.

In effect, he wondered whether Chambri culture had become too lax. There was no longer any solidarity. Previously, a man like Kwoli controlled one type of fish, and others like Tari and Pandu controlled something else. They all worked together. There was, Soway said, "unity." Now people were using power perversely, for example, by making the wind perilously strong for fishing or travel and then demanding money to calm the waters. Those doing this were not even the people who should have these powers. They had bought them from their true owners for purposes of extortion. Echoing a widespread sentiment, Soway described them with the English word "corrupt."

\section{The Capitalism of Chambri Cosmology}

In this article, we have conveyed a village-based minihistory of one set of Chambri shifts, drifts, and stocktakings over the last forty plus years: 
a history of choices, decisions, and ramifying ripples. As should be clear, we do not mean this history as an allegory of a lost Eden. All civilizations have their discontents, and those discontents among the Chambri had long been close to the surface. Significant among them was intergenerational conflict wrought by earlier shifts and decisions, which resulted in young lives demanding fresh choices and fresh decisions. However, in embracing what was in essence a different ontology and logic, these young lives precipitated, as Firth would have noted, a structural change—one that, in neoliberalspeak, was a game-changing structural adjustment. ${ }^{11}$ That is to say, the environment of environmental control significantly shifted as the regulation of the winds, water, and fish moved from a cosmological division of labor to a for-profit, "business" enterprise.

The result was a striking example of totemic ontology transformed by the logic of capitalism. Indeed, to return to Bourdieu's language (I983), so striking was it that many Chambri, who as young lives had themselves struggled against the "effects of power," now fretted about the "knowledge, competence, and qualification" of the "young challengers." Impelled to take stock of what might become the new doxa, they returned to Foucault's question, "Who are we?" (I982). In sum, they were pondering, "What have we become?"

Such ponderings about choices, decisions, and consequences may well be increasingly pressing in the future. Becoming businesspeople who sell totemic regulation of wind, water, and fish may presage a more ominous turn of events, one in which the resources themselves are up for sale or up for grabs. And this could be the case if the nearby Chinese-financed "Frieda River" gold and copper mine comes to fruition. ${ }^{12}$ To be sure, many Chambri do look forward to the business opportunities the mine may provide. Klara, for instance, anticipates renting her permanent-materials house to mine workers needing a break. She thought they might enjoy a weekend of sitting on her porch, looking across beautiful Chambri Lake, and partaking of freshly cooked pacu. Unfortunately, the location of the mine also means that its likely toxic releases would permeate an immense watershed, including the lake, the Sepik River, and many of the river's tributaries. Hence, the capitalism of Chambri cosmology-the logic that had led to making a business out of Chambri modes of environmental regulation-may ultimately have to deal with the business of environmental despoliation. 


\section{Notes}

I Perceptions of environmental changes are widespread in Papua New Guinea. See Lipset 20II, 20I3, and 20I4. Compare, as well, Kirsch 2006; Jacka 20I5; West 20I6; and contributions to Wagner and Jacka 20I8. For the wider Pacific, see Rudiak-Gould 20I4; van Meijl 20I 5; Cox and others 2018.

2 Our writings of most relevance to the topic at hand are: Gewertz I977, I983; Errington and Gewertz 1987; Gewertz and Errington I991, I999.

3 All names in this paper are pseudonyms.

4 Compare Silverman 201 8, which discusses local reactions to pacu elsewhere in the Sepik.

5 David Lipset, focusing on the Murik Lakes at the mouth of the Sepik River, has also considered changes in the totemic regulation of the environment (20I I, 20I3, 20I4).

6 For significant analyses of Christianity, modernity, youth, gender, and the good life in Papua New Guinea and elsewhere in the Pacific, see Robbins 2004; Barker I990, 20I 2; Tomlinson and McDougall 20I3; Handman 20I 5; Minnegal and Dwyer 2017; Stead 2018; Gregory and Altman 2018.

7 We did describe this event, not in a book, but in an article. See Errington and Gewertz 200I.

8 Others focused on Papua New Guinea have written about the shifting relationship between nature and the human activities to control it. See, especially, Robbins I995; Biersack I999; Brunois I999; West 2006; Jacka 2015.

9 Concerning the collapse of the regional tourist trade, see Silverman 20 I 3.

Io Marijuana use has become widespread among young men in Papua New Guinea. See Halvaksz and Lipset 2006; Lipset 2006.

I I For a more extended discussion of ontological shifts among Chambri, see Gewertz and Errington 2016.

I2 About the Frieda mine, see Silverman 2018.

\section{References}

Barker, John, editor

I990 Christianity in Oceania. Lanham, NY: University Press of America. Barker, John

2012 The Politics of Christianity in Papua New Guinea. In Christian Politics in Oceania, edited by Matt Tomlinson and Debra McDougal, I 46-I 70. Oxford: Berghahn.

Bateson, Gregory

I946 Arts of the South Seas. Arts Bulletin 28 (2): I I9-I23.

Bauman, Richard

I975 Verbal Art as Performance. American Anthropologist 77 (2): 290-3 I I. 
Biersack, Aletta

I999 The Mount Kare Python and His Gold: Totemism and Ecology in the Papua New Guinea Highlands. American Anthropologist IOI (I): 68-87.

Bourdieu, Pierre

I983 The Field of Cultural Production. Cambridge, uk: Cambridge University Press.

Brunois, Florence

I999 In Paradise, the Forest is Open and Covered in Flowers. In Expecting the Day of Wrath: Versions of the Millennium in Papua New Guinea, edited by Christin Kocher Schmid, I I I-I30. Boroko, PNG: The National Research Institute.

Cox, John, Glen Finau, Romitesh Kant, Jope Tarai, and Jason Titifanue

2018 Disaster, Divine Judgment, and Original Sin: Christian Interpretations of Tropical Cyclone Winston and Climate Change in Fiji. The Contemporary Pacific 30 (2): 380-4 Io.

Errington, Frederick, and Deborah Gewertz

I987 Cultural Alternatives and a Feminist Anthropology. Cambridge, UK: Cambridge University Press.

200I On the Generification of Culture: From Blow Fish to Melanesian.

Firth, Raymond Journal of the Royal Anthropological Institute 7 (3): 509-525.

I954 Social Organization and Social Change. Journal of the Royal Anthropological Institute of Great Britain and Ireland 84 (I/2): I-20.

Foucault, Michel

I982 The Subject and Power. Critical Inquiry 8 (4): 777-795.

Gewertz, Deborah

I977 "On Whom Depends the Action of the Elements": Debating among the Chambri People of Papua New Guinea. The Journal of the Polynesian Society 86 (3): 339-353.

I983 Sepik River Societies: A Historical Ethnography of the Chambri and Their Neighbors. New Haven, Ст: Yale University Press.

Gewertz, Deborah, and Frederick Errington

I99I Twisted Histories, Altered Contexts: Representing the Chambri in a World System. Cambridge, uk: Cambridge University Press.

I999 Emerging Class in Papua New Guinea: The Telling of Difference. Cambridge, uk: Cambridge University Press.

20I6 Retelling Chambri Lives: Ontological Bricolage. The Contemporary Pacific 28:347-38I.

Gregory, Chris, and Jon Altman

2018 The Quest for the Good Life in Precarious Times. Acton, ACT: ANU Press. 
Halvaksz, Jamon, and David Lipset

2006 Another Kind of Gold: An Introduction to Marijuana in Papua New

Guinea. Oceania 76:209-219.

Handman, Courtney

2015 Critical Christianity. Oakland: University of California Press.

Jacka, Jerry

20I 5 Alchemy in the Rain Forest: Politics, Ecology, and Resilience in a New Guinea Mining Area. Durham, NC: Duke University Press.

Kirsch, Stuart

2006 Reverse Anthropology: Indigenous Analysis of Social and Environmental Relations in New Guinea. Stanford, CA: Stanford University Press.

Lipset, David

2006 Tobacco, Good and Bad: Prosaics of Marijuana in a Sepik Society. Oceania 76 (3): 245-257.

20I I The Tides: Masculinity and Climate Change in Coastal Papua New Guinea. Journal of the Royal Anthropological Institute I7 (I): 20-43.

20I3 The New State of Nature: Rising Sea-Levels, Climate Justice, and Community-Based Adaptation in Papua New Guinea (2003-20I I). Conservation and Society I I:I44-I 57.

20I4 Place in the Anthropocene: A Mangrove Lagoon in Papua New Guinea in the Time of Rising Sea-Levels. HAU: Journal of Ethnographic Theory 4 (3): $215-243$.

Mathie, Alison, and Elizabeth Cox

I987 New Directions for Women in Non-Formal Education. Waigani, PNG: Office of Women's Affairs.

Minnegal, Monica, and Peter Dwyer

20I7 Navigating the Future. Acton, ACT: ANU Press.

Robbins, Joel

I995 Dispossessing the Spirits: Christian Transformations of Desire and Ecology among the Urapmin of Papua New Guinea. Ethnology 34 (3): 2 I I-224.

2004 Becoming Sinners: Christianity and Moral Torment in a Papua New Guinea Society. Berkeley: University of California Press.

Rudiak-Gould, Peter

20I4 Climate Change and Accusation: Global Warming and Local Blame in a Small Island State. Current Anthropology 55 (4): 365-386.

Sahlins, Marshall

I985 Islands of History. Chicago: University of Chicago Press.

I988 Cosmologies of Capitalism: The Trans-Pacific Sector of "the World System." Proceedings of the British Academy 74:I-5I. 
2008 Alterity and Autochthony: Austronesian Cosmographies of the Marvelous. Raymond Firth lecture delivered at the meetings of the Silverman, Eric European Society for Oceania, Verona, Italy, I I July.

20I3 After Cannibal Tours: Cargoism and Marginality in a Post-Touristic Sepik River Society. The Contemporary Pacific 25 (2): 22 I-257.

2018 The Sepik River, Papua New Guinea: Nourishing Tradition and Modern Catastrophe. In Island Rivers: Fresh Water and Place in Oceania, edited by John Wagner and Jerry Jacka, I87-22I, Canberra: ANU Press.

Stead, Victoria C

2018 Becoming Landowners. Honolulu: University of Hawai'i Press.

Tomlinson, Matt, and Debra McDougall, editors

20I3 Christian Politics in Oceania. New York: Berghahn Books.

van Meijl, Toon

2015 The Waikato River: Changing Properties of a Living Māori Ancestor. Oceania 85 (2): 219-237.

Wagner, John, and Jerry Jacka, editors

2018 Island Rivers: Fresh Water and Place in Oceania. Canberra: ANU Press.

West, Paige

2006 Conservation Is Our Government Now: The Politics of Ecology in Papua New Guinea. Durham, NC: Duke University Press.

2016 Dispossession and the Environment: Rhetoric and Inequality in Papua New Guinea. New York: Columbia University Press.

\section{Abstract}

Raymond Firth argued in "Social Organization and Social Change" that, although structure provides a framework for action, circumstances may lead to "fresh choices" and "fresh decisions" with results that "ripple" throughout a structural framework and, sometimes, beyond it; when this departure from a structure becomes permanent, the result is social change (1954). During our longterm fieldwork among the Chambri people of Papua New Guinea's East Sepik Province, we noted such ripple effects, especially as Chambri realized that they could make fresh choices and decisions in order to create new ripples. Notably, some of these new ripples affected the totemic regulation of the Chambri world. Simply put, the ontology and logic of Chambri totemism-what had been the environment of environmental regulation-became open to capitalist-inflected choices and decisions. Here we consider this emergent capitalism of Chambri cosmology as a historical process of social change, one arising from a conjuncture 
with the "cosmologies of capitalism," to reference Sahlins's significant discussion (I988). Along the way, we appraise the fate of ontological purity at a time when the assumptions and practices of Chambri totemism, those constituting the relationship of humans to nonhumans, have become substantially reformulated. What does it signal for Chambri that the wrong sorts of people may be making for-profit choices and decisions about the actions of the elements while, at the same time, these elements-wind, water, and fish-have become increasingly obstreperous, apparently acting on their own volitions?

KEYWORDs: Raymond Firth, social change, totemism, cosmology, capitalism, Papua New Guinea, ontology. 